\title{
The Effects of Integrating Board Games into Ice-breaking Activities in a Fifth-Grade English Class to Reduce Students' Anxieties
}

\author{
Chung-yi Chao ${ }^{1} \&$ Sa-hui Fan ${ }^{1}$ \\ ${ }^{1}$ Taichung University of Education, Taiwan \\ Correspondence: Sa-hui Fan, Taichung University of Education, 140, Min-sheng Rd., West Distr., Taichung City, \\ Taiwan.
}

Received: July 7, 2020

Accepted: August 10, 2020

Online Published: August 13, 2020

doi: 10.5539/elt.v13n9p40

URL: https://doi.org/10.5539/elt.v13n9p40

\begin{abstract}
Elementary-level English teachers in Taiwan were facing problems caused by students' bimodal distribution of English achievements. Many of the teachers tried new teaching tools to eliminate the obstacles of teaching. This study was based on a quasi-experimental research design and supplemented by qualitative feedback to explore how the new teaching method, ice-breaking board games, could reduce students' anxieties of learning English. The researchers combined popular board games, Halli Galli and Alles Tomate, with English words and sentences in ice-breaking activities for 10 weeks in two fifth-grade English classes in Taiwan. Forty-eight fifth-grade students were invited to participate in the study and randomly divided into two equal-sized classes. One class was selected as the experimental group, and the other as the control group. The study lasted for 10 weeks. The Foreign Language Classroom Anxiety Scale (FLCAS) developed by Horwitz et al. (1986) was employed as the instrument to measure students' English learning anxieties. Quantitative data were analyzed by using independent-sample and paired-sample $t$-tests as well as descriptive statistics, whereas qualitative data (which included the participating students' feedback and teacher's reflection notes) were analyzed through content analysis. The research findings suggested that integrating board games in English teaching as ice-breaking activities did not effectively reduce students' overall foreign language anxiety. However, the descriptive statistics and qualitative data revealed that the constructs of anxiety for both groups had changed in opposite directions, and ice-breaking board games appeared to be more impactful in reducing certain aspects of anxiety construct, namely, communication apprehension.
\end{abstract}

Keywords: Foreign Language Learning Anxiety, Board Games, elementary schools

\section{The Effects of Integrating Board Games as Ice-breaking Activities in a Fifth-Grade English Class to Reduce Students' Anxieties}

In some Asian countries, English is not only an international communication tool but also a prestigious mark to express the speaker's highly regarded social and cultural background. In 2005, Taiwan launched a language policy to teach English in Grade 3. However, many parents with better financial backgrounds might have sent earlier their children to bilingual kindergartens or preschools (Liao, 2007). By contrast, children from disadvantaged backgrounds might fall far behind in English proficiency in their early schooling years because the early bilingual education is not affordable. Many Taiwanese researchers and scholars have recognized and identified this problem of the bimodal distribution of English abilities in elementary schools (Chang, 2009). Elementary English teachers are also quite aware of the teaching difficulties caused by a bimodal distribution (Lin, 2009) and have attempted several new instructional designs to solve this dilemma. Board games have been seen as one of the most popular instructional tools in the recent decade. Many primary teachers believe that such new instructional tools can easily attract students' attention and reduce their English learning anxiety, especially for lower achievers. However, few studies have supported this unexamined belief. Hence, to explore how board games influence young learners' affective domain of learning English, this study is designed to answer the following questions, adopting a quasi-experimental research design supplemented by qualitative data:

1. Do ice-breaking board games reduce the overall anxiety of young learners' English learning?

2. Do ice-breaking board games reduce any construct aspect of young learners' English learning anxieties? 
3. What pedagogical applications can be drawn from the results for elementary teachers of EFL facing bimodal distributions?

\section{Literature Review}

The literature review section includes the following: the history and categorization of board games, the development of the research, the constructs of foreign language anxiety, and the causes of foreign language learning anxiety.

\subsection{Board Games}

Games played on table tops may be referred to by various names due to different allotted time and locations. The common English name for table-top games is "board game." Gobet et al. (2004) explained that board games were caharcterized by the following features: (1) There must be game rules (including the numbers of cards, game objects, players and their roles), and (2) the layout and the movements of the game objects must influecne the results of games. Fagan (2004) indicated that playing games was not only human nature but could also be a learning medium for children.

Types of board games. Parlett (1999) categorized board games into four types: classic games, specialist games, family games, and pulp games. Furthermore, the most famous board game website, Board Game Geek, was launched in 2000. This website divides board games into eight categories: abstract games, children's games, customizable games, family games, party games, strategy games, thematic games, and war games. In spite of the different categorizations, the common type of game, family games, are most suitable and popular for children of all grades.

Board games and learning. "Playing" has been an important process in human development. Lev Vygotsky claimed that children's development was mainly enhanced by "playing" (Mostowfi et al., 2016). Furthermore, Abbot (2000) mentioned that the significant contribution of playing was to make the child feel context-related. Smith (2006) also emphasized that most of child game players could share better experiences in related contexts. This context relatedness of games could be quite helpful in learning a new language.

Moreover, Siegler and Ramani (2008) discovered that students from lower social-economic status (SES) backgrounds had fewer experience with board games. After having played the board games for some time, the variations of calculating abilities among lower SES students and middle-class students were reduced. Hence, the contributions of board games are not only limited to entertaining children but also enhancing players' abilities to acquire new knowledge or skills.

Board Games and Language Learning. Due to the fact that board games are characterized by a complete set of game rules as well as context relatedness, they are easier to adopt as language learning tools (Smith, 2006). Lee (2012) claimed that a well-developed board game was highly educational because game players would need to learn a new set of game knowledge and should be able to speak the target language of the games. Therefore, it is highly feasible for language teachers to adopt board games as instructional tools.

In addition, several studies conducted in Taiwan have specifically indicated that adopting board games in elementary-level English teaching can effectively enhance young learners' achievements in English vocabulary, English speaking or listening ability, and English learning attitude and motivation (Lo, 2016; Wu, 2016; Chi, 2016; Cheng, 2016; Lin. 2015). The type of board games used in the five studies were highly similar, and all belonged to family or party game types. However, there is little research examining how the use of board games in English teaching can influence the affective domain of young learners. This study was thus designed to bridge this research gap.

\subsection{Foreign Language Learning Anxiety}

Affective filter hypothesis. Stephen Krashen (1982) proposed the affective filter theory to explain how affective factors as a transparent wall interfered with the effectiveness of learning foreign languages. The thickness or strength of the affective filter would influence how many new language inputs that learners were able to receive. A learner holding negative affections towards learning a foreign language may only receive partial or little new language inputs, because his or her affective filter becomes so thick that many new language inputs would be screened out. Even though this learner might understand part of the new input, the affective filter still would prevent the new inputs from reaching the learner's "language acquisition device." Hence, the thick affective filter reduces the effectiveness of learning a foreign language. This hypothesis helps language teachers understand that an effective teacher should provide not only comprehensible input but also a learning context creating thin affective filters for learners (Krashen, 1982). Methods to lower language learners' affective factor, such as anxiety, has become an issue of concern for many researchers of foreign language teaching. 
Definition of Anxiety. Foreign language learning anxiety is distinguished from general anxiety because it belongs to situation-specific anxiety (MacIntyre \& Gardner, 1991). Spielberger (1983) defined anxiety as a subjective feeling of tension, apprehension, and nervousness. Horwitz et al. (1986) also mentioned that anxiety would stimulate autonomic nerves. Furthermore, Speilberger (1983) divided anxiety into state anxiety and trait anxiety. State anxiety is referred to as the temporary uncomfortable feelings triggered by temporary situations, such as tests, whereas trait anxiety refers to long-term emotions situated in one's personality.

Definition of Foreign Language Learning Anxiety. The anxiety of learning a foreign language has long been identified. Clement, in the 1980 's, attempted to define the anxiety of learning a foreign language as a composite (Trang, 2012). It dealt mostly with learners' feelings. Horwitz et al. (1986) mentioned that the anxiety of learning a foreign language occurred specifically in a foreign language classroom and differed from general forms of anxiety. Therefore, the anxiety of learning a foreign language should not be seen as a combined outcome of many other forms of anxieties. Rather, it should be seen as a specific situtated type of anxiety challening the individual's self-identity, beliefs, feelings, and behaviors in a foreign language classroom.

In Trang's (2012) review, Horwitz et al. (1986) were the first researchers to identify and conceptualize the type of anxiety produced in a specific foreign language classroom situation. Many other researchers have continued to develop this line of research. Young (1992) indicated that the anxiety of learning a foreign langauge was psychological and involved complex feelings created only in foreign lagnauge learning. MacIntyre (1983) proposed that the anxiety of foreign language learning was specifically situated and not highly relevant to other forms of anxiety. In addition, MacIntyre and Gardner in 1999 proposed the construct of foreign language learning anxiety and defined it as a tense and uneasy feeling in foreign langauge learning. The uneainess may come from the learning contents, such as listening and speaking, or negative evaluations from others. The Taiwanese researcher, Cheng (1999), made a similar assertion, namely, that foreign language learning anxiety was especially situated in foreign language learning and was different from general forms of anxiety.

\subsection{Constructs of Foreign Language Learning Anxiety}

The theoretical ground of foreign language learning anxiety had not been well established until 1986 when Horwitz et al. (1986) published a series of papers on its conceptualization. The researchers proposed a systematical concept to develop the specific construct of foreign language learning anxiety and to find the specific type of anxiety that was affected by academic and social evaluations. Foreign language learning anxiety can be divided into three aspects: communication apprehension, test anxiety, and fear of negative evaluation (Cheng, 1999; Chou et al., 2009).

Communication Apprehension. Communication apprehension refers to anxieties and fears that occur while communicating with others. In particular, it regards face-to-face communication in pairs or groups. In addition to oral communication difficulties, communication anxiety also refers to stage fright. Furthermore, Horwitz et al. (1986) categorized hearing anxiety (receiving anxiety) as one type of communicataion apprehension. Huang (2012) mentioned that communication anxiety especially referred to the discomfort of learners brought by speaking the foreign language in front of others. When learners are unable to use the foreign language to express their feelings fluently or to understand the interlockter, self-questionning and self-doubt would easily be produced. MacIntyr and Gardner (1991) also found that most foreign language learners became anxious when speaking the target language. Hence, communication apprehension is an issue that foreign language practicioners should pay serious attention to.

Test Anxiety. Test anxiety is the type of anxiety caused by the fear of failure. Learners with this type of anxiety usually place unrealistic expectations on themselves and would feel as failures if they did not perform perfectly at tests (Horwitz et al., 1986). Huang (2012) described how test anxiety was often seen in foreign language learning. Some students learn a foreign language for the purpose of passing tests instead of communicating with people speaking the target language (Gregersen \& Horwitz, 2002). Cheng in 1999 also mentioned that foreign language classes often included formative evaluation, and students might unavoidably make more or less mistakes at this type of evaluation. This learning process might cause considerable test anxiety.

Fears of Negative Evaluation. Fears of negative evaluation refers to the disturbance caused by others' feedback. These fears might produce learners' avoidance of being evaluated because of the predicted negative feedback from others. Fears of negative evaluation have similarities with test anxiety but are not limited to the test circumstances. The negative evaluation might come from social or critical scenarios, such as job interviews or conversations in a foreign language classroom (Horwitz et al., 1986). Horwitz et al. mentioned that oral performance needed to be constantly evaluated in foreign langauge learning. Therefore, learners were more often 
challenged by others' negative feedback and laughter. Learners of a foreign language might cultivate higher sensitivy of negative evaluation because of the frequent confrontations of mistakes.

\section{Methodology}

This study was designed as a quasi-experimental research and was supplemented by qualitative feedback to explore how Taiwanese elementary students responded to board games as icebreakers in English classes and how well the board games reduced students' anxieties. The researchers combined popular board games, Halli Galli and Alles Tomate, with English words and sentences chosen from an EFL textbook published in Taiwan. A 5-minute game time was implemented at the beginning of every English class. Forty-eight Taiwanese fifth-grade students were randomly divided into two classes of equal size. One class was selected as the treatment group, and the other was the control group. This study lasted for 10 weeks. There were 2-hour English teachings per week for each group. The Foreign Language Classroom Anxiety Scales (FLCAS) developed by Horwitz et al. (1986) was employed as the instrument to measure students' anxieties. Quantitative data was analyzed by $t$-test (independent-sample and paired-sample) and descriptive statistics, whereas the qualitative data, the participating students' feedback, and the instructor-researcher's reflection journal were analyzed through content analysis.

\subsection{Pretest and Post-Test}

The scores that both experimental and the controlled groups received after taking the Chinese version of the FLCAS (Horwitz et al., 1986) were the results of the pretest. After 10 weeks of the experiment, both groups were tested again using the same scale, and their scores were the results of the post-test. The FLCAS is a 5-point Likert-type scale consisting of 28 questions (Horwitz, 2008). It is constructed of three aspects: communication anxiety, test anxiety, and fears of negative feedback. The "foreign language" in the scale questions is referred to English in the Taiwanese context. To adapt FLCAS to the needs of elementary students in Taiwan, Tseng (2005) translated the scale into Chinese, modified the questions, and conducted an internal consistency test that involved 261 Taiwanese elementary students. The overall Cronbach $\alpha$ was .9410 .

\subsection{Independent Variable}

The participants were divided into two groups: the treatment group and the control group. The treatment for the treatment group was board games used in 5- to 10-minute ice-breaking activities at the beginning of every English class. The board games used as icebreaker were independent variables. The teaching methods in these two classes were the same, except the board games used as icebreakers in the treatment group.

\subsection{Dependent Variable}

The dependent variable in this study was the results of FLCAS for both the treatment and control groups at the pre- and post-tests.

\subsection{Other Factors}

The other controlled factors, including time length, class time, teaching materials, and the instructor are introduced below.

Time Length. The time length of experiments was 10 weeks totally, which included the first week of pretest and the tenth week of post-test. The treatment and the control groups participated in the study simultaneously.

Class Time. From the second to the ninth week, both classes had two 40-minute English classes each week.

Teaching Materials. The teaching materials used in the two groups were the same, except that the ice-breaking activities of English board games were implemented at the beginning of the English classes of the treatment group.

The instructor. The English instructor of the two groups were the same.

\subsection{The Participants}

This study adopted convenience sampling to invite 48 Grade 5 students of a school located in the mountainous central of area of Taiwan. The 48 participants were randomly assigned into two classes, the treatment and the control groups. There were 24 students in each class, and the gender proportions were similar.

According to the curriculum guidelines of basic education released by the Taiwanese Ministry of Education, English class starts formally from Grade 3 for every child. Most Grade 5 students in Taiwan have the basic English abilities in listening, speaking, reading, and writing necessary to play English board games. 


\subsection{Qualitative Data Collections}

Qualitative data was collected after each English class. The data included the participants' feedback (see Appendix A and B) and the instructor/researcher's teaching journal. Both the treatment and control groups needed to fill in the feedback forms after every English class. The feedback forms were composed of open-ended questions. The instructor or researcher journal logs were kept after every English class and covered the following topics: the teaching process, how the board games were integrated into the English classes, the participating students' responses, and the instructor's reflections.

\subsection{Criteria of Selecting the Board Games}

The criteria of selecting the board games included the following: (1) suitable for students of elementary schools; (2) easily integrated into English classes; (3) having precise but simple rules; (4) suitable for being repeated within a short period of time.

The two board games selected and modified as icebreakers were (1) Halli Galli (http://www.swanpanasia.com/products/halli-galli) and (2) Alles Tomate (http://www.swanpanasia.com/products/alles-tomate).

\subsection{Data Analysis}

After data collection was completed, descriptive statistics, independent-samples $t$ test, and paired-samples $t$ test were used to analyze the quantitative data. On the other hand, the 24 students in the treatment group were asked to turn in their written feedback regarding the ice-breaking board games in the 10-week experiment. The researcher also kept field notes during the 10 weeks. The qualitative data were analyzed through content thematic analysis (Krippendorff et al., 2008; Roberts, 1997).

\section{Findings}

In this study, the major data were gleaned quantitatively, whereas the qualitative data was gleaned supplementarily. Both types of data indicated similar findings: The overall anxiety of the experimental group was not reduced in the experimental group significantly after a 10-week intervention of ice-breaking board games. However, the anxiety aspect and communication apprehension of the experimental group were slightly appeased, and test anxiety along with fears of negative apprehension increased.

\subsection{Analysis of Quantitative Data}

Findings from the quantitative analysis were displayed in terms of four main points, including (1) analyses of in-group difference of both experimental and the control groups, (2) between-group comparison of the pretest, (3) between-group comparison of the post-test, and (4) in-group analyses of construct aspect of anxiety in both groups. The total between-group anxiety difference of the post-test did not reach the significant level. This meant that the ice-breaking board games did not effectively reduce the overall anxiety of learning English in the experimental group. However, the indicators of the three construct aspects of anxiety of both groups changed in different directions during the 10 weeks of ice-breaking board games. The communication apprehension of the experimental group appeared to be slightly reduced, whereas test anxiety and fears of negative feedback increased slightly. On the other hand, the test anxiety of the control group appeared to be slightly reduced, whereas the communication apprehension and fears of negative feedback increased slightly.

Quantitative data included the scores of pre- and post-tests (FLACAS) of all participants. The valid questionnaire feedback rate of the pretest was $100 \%$, and that of the post-test was $98 \%$.

The In-Group Difference Analyses of Both Groups. Paired sample $t$-test, independent sample $t$-test, and descriptive statistics were used to analyze the in-group differences of both the treatment and control groups at pre- and post-tests. The results are presented in Table 1. 
Table 1. In-Group Difference Analysis

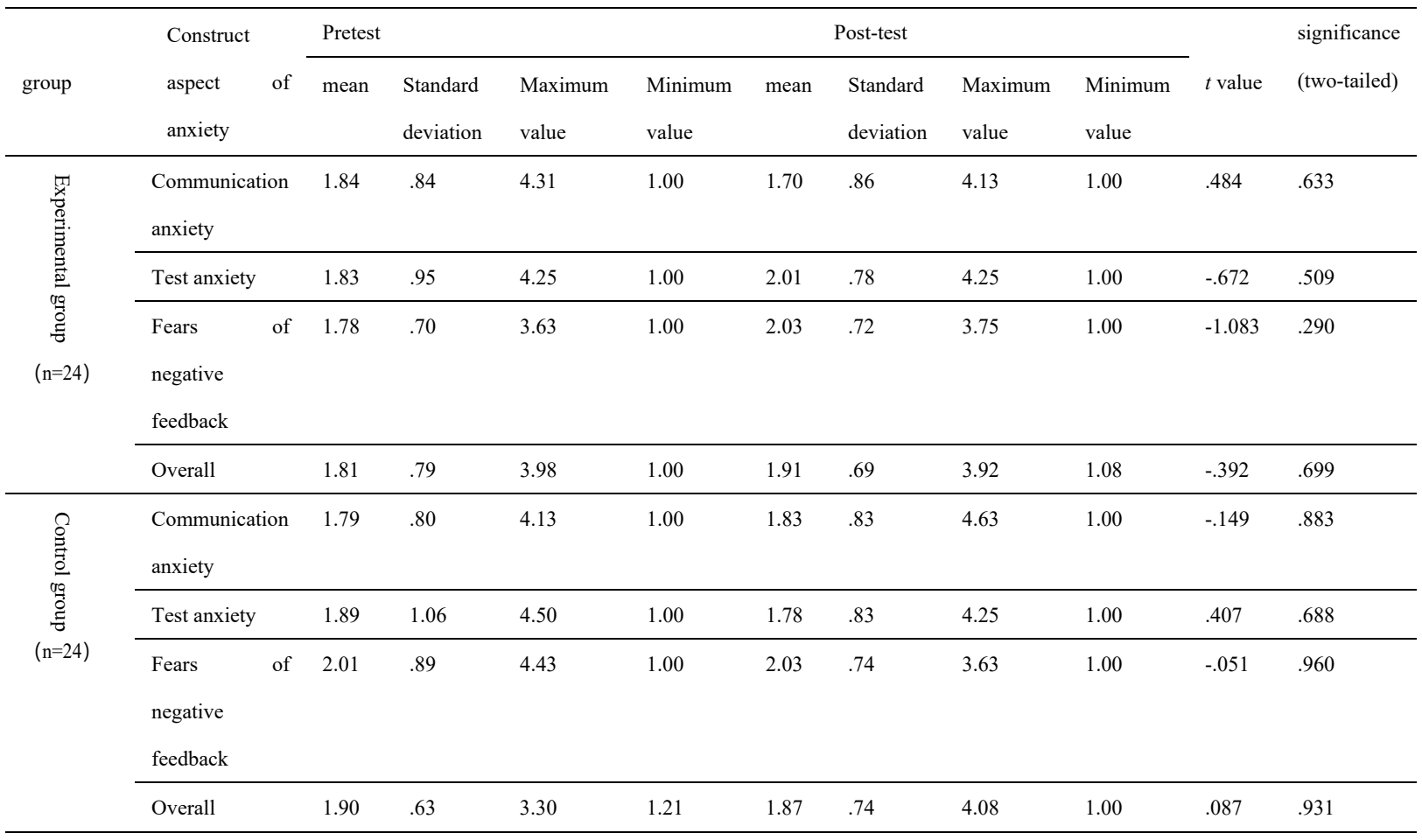

$* \mathrm{P}<.05$

Two main findings can be drawn from Table 1: (1) There was no significant in-group differences between the pre- and post-tests in the aspect of "communication apprehension", "test anxiety", and "fears of negative feedback" in both groups; (2) there was no significant in-group differences between the pre- and post-tests in overall anxiety for both groups.

In the in-group analysis of communication apprehension (experimental group: $t=.484, p=.633$; control group: $t$ $=-.149, p=.883$ ), test anxiety (experimental group: $t=-.672, p=.509$ : control group: $t=.407 ; p=.688$ ), and fears of negative evaluation (experimental group: $t=-1.083, p=.290$; control group: $t=-.051, p=.960$ ), the $p$ values of both groups were larger than .05 . The results of paired-sample $t$-test did not reach the significant level. In other words, the difference between the pre- and post-tests in the three aspects of both groups did not reach the significant level. Nevertheless, in terms of mean scores, that of the experimental group on communication apprehension was the only aspect that was reduced, whereas those on test anxiety and fears of negative evaluation increased.

The experimental group's mean score for communication apprehension was 1.84 for the pretest and 1.70 for the post-test. In addition, the maximum score for communication anxiety was 4.31 at the pretest and 4.13 at the post-test. Both numbers might indicate that after the board game ice-breaking intervention, the communication apprehension of the treatment group was reduced, despite that the lack of significant differences between the two groups.

The in-group difference of communication apprehension of the control group went in the opposite direction. The control group's mean score for communication apprehension was 1.79 for the pretest and 1.83 for the post-test. In addition, the maximum score of communication anxiety was 4.13 for the pretest and 4.63 for the post-test. Both numbers possibly indicated that the communication apprehension of the control group increased slightly, despite the lack of significant differences between the two groups.

The Between-Group Comparison of the Pretest. The results of the pretest from both groups were compared using independent sample $t$ test as shown in Table 2. 
Table 2. Between-Group Analysis of the Pretest

\begin{tabular}{|c|c|c|c|c|c|c|}
\hline \multirow[b]{2}{*}{ Aspect } & \multicolumn{2}{|c|}{ Experimental group $(n=24)$} & \multicolumn{2}{|c|}{ Control group $(n=24)$} & \multirow[b]{2}{*}{$t$ value } & \multirow{2}{*}{$\begin{array}{l}\text { Significance } \\
\text { (two-tailed) }\end{array}$} \\
\hline & mean & $\begin{array}{l}\text { Standard } \\
\text { deviation }\end{array}$ & Mean & $\begin{array}{l}\text { Standard } \\
\text { deviation }\end{array}$ & & \\
\hline $\begin{array}{l}\text { Communication } \\
\text { anxiety }\end{array}$ & 1.84 & .84 & 1.79 & .80 & .120 & .905 \\
\hline Test anxiety & 1.83 & .95 & 1.89 & 1.06 & -.336 & .739 \\
\hline $\begin{array}{l}\text { Fears of negative } \\
\text { feedback }\end{array}$ & 1.78 & .70 & 2.01 & .89 & -1.101 & .277 \\
\hline Total & 1.81 & .79 & 1.90 & .63 & -.454 & .652 \\
\hline
\end{tabular}

$* \mathrm{P}<.05$

The results show that between-group differences for anxiety for the pretest generally $(t=-.454$ and $p=.652)$ or in specific aspects (communication anxiety: $t=.120, p=.905$; test anxiety: $t=-.336, p=.739$; fears of negative feedback: $t=1.101, p=.277)$ were not significant. The levels of anxieties for the experimental group and the control group at the pretest were similar.

In addition, both groups had low levels of anxiety at the pretest. The mean anxiety scores of both groups at the pretest either in total (1.81 and 1.90, respectively) or in specific aspects (communication apprehenshion: 1.84 and 1.79, respectively; test anxiety: 1.83 and 1.89, respectively; fears of negative feedback: 1.78 and .89, respectively) were all under 3 . These results indicate that both groups had low levels of anxiety at the pretest.

The Between-Group Comparison of the Post-Test. The results of the post-test from both groups were compared using independent-sample $t$-test as shown in Table 3.

Table 3. Between-Group Analysis of the Post-Test

\begin{tabular}{|c|c|c|c|c|c|c|}
\hline \multirow[b]{2}{*}{ Aspect } & \multicolumn{2}{|c|}{ Experimental group $(\mathrm{n}=24)$} & \multicolumn{2}{|c|}{ Control group $(n=24)$} & \multirow[b]{2}{*}{$t$ value } & \multirow{2}{*}{$\begin{array}{l}\text { Significance } \\
\text { (two-tailed) }\end{array}$} \\
\hline & mean & $\begin{array}{l}\text { Standard } \\
\text { deviation }\end{array}$ & Mean & $\begin{array}{l}\text { Standard } \\
\text { deviation }\end{array}$ & & \\
\hline $\begin{array}{l}\text { Communication } \\
\text { anxiety }\end{array}$ & 1.70 & .86 & 1.83 & .83 & -.502 & .618 \\
\hline Test anxiety & 2.01 & .78 & 1.78 & .83 & .988 & .328 \\
\hline $\begin{array}{l}\text { Fears of negative } \\
\text { feedback }\end{array}$ & 2.03 & .72 & 2.03 & .74 & -.009 & .993 \\
\hline Total & 1.91 & .69 & 1.87 & .74 & .172 & .864 \\
\hline
\end{tabular}

$* \mathrm{P}<.05$

The statistical results revealed that between-group differences of anxiety at the post-test either in total $(t=.172$ and $p=.864$ ) or in specific aspects (communication apprehension: $t=-.502, p=.618$; test anxiety: $t=-.988, p$ $=.328$; fears of negative feedback: $t=-.009, p=.993$ ) were all not significant. The levels of anxieties of the treatment group and the control group at the post-test were similar.

In addition, both groups had low levels of anxiety at the post-test. The anxiety mean scores of both groups at the post-test either in total (1.91 and1.87, respectively) or in aspects (communication apprehension: 1.70 and 1.83 , respectively; test anxiety: 2.01 and 1.78, respectively; fears of negative feedback: 2.03 and 2.03, respectively) were all under 3 . These results indicate that both groups had low levels of anxiety at the post-test.

The statistical results possibly suggested that both groups had low levels of anxiety before and after the treatment of using board games as icebreakers in English classes. The ice-breaking board games did not appear to reduce the overall anxiety levels of learners who had already shown low levels of anxiety at first.

The in-group analyses of anxiety construct. In the analysis of the anxiety construct of the experimental group, results revealed that only communication apprehension (pretest main score $=1.84$; post-test mean score $=1.70$ ) was slightly reduced, but the test anxiety (pretest main score $=1.83$; post-test mean score $=2.01$ ) and fears of negative evaluation (pretest main score $=1.78$; post-test mean score $=2.03$ ) increased slightly.

In the analysis of the anxiety construct of the control group, the results for the descriptive analysis demonstrated that only test anxiety (pretest main score $=1.89$; post-test mean score $=1.78$ ) was slightly reduced, but the communication apprehension (pretest main score $=1.79$; post-test mean score $=1.83$ ) and fears of negative evaluation (pretest main score $=2.01$; post-test mean score $=2.03$ ) increased slightly. 
The statistical analyses indicated that the ice-breaking board games did not significantly help reduce the overall anxiety of English learning. However, the descriptive statistics suggested that board games indeed changed young leaners' anxiety constructs in different directions. The descriptive results indicated that ice-breaking board games might help reduce one aspect of the anxiety construct of English learning, namely, communication apprehension.

\subsection{Analysis of Qualitative Data}

In general, the qualitative data echoed the statistical results and showed that ice-breaking board games helped increase the pleasure of learning and created a warm and positive environment for learning English to reduce communication apprehension. Qualitative data were garnered mainly from the instructor/researcher's teaching journals and students' feedback after every class.

During the 10-week experiment, based on the instructor's teaching journals, it was observed that students' communication apprehension appeared to decrease, but the overall anxiety of the experimental group was not significantly reduced. This might have been caused by the fact that some students participated in the board games while having high levels of fear of negative evaluation. In particular, when school tests were approaching, fears of negative evaluation combined with test anxiety remained high.

Students' appeased communication apprehension was mainly observed in the researcher's teaching logs:

Students read out the words louder than before (when they didn't play the board games)! Now they are familiar with the words and sentence patterns at the games. The gaming atmosphere became so heated!

The experimental group's qualitative feedback show that the board games provided students with a fun environment to use new English vocabulary to communicate. There were abundant qualitative feedback illustrating this:

\section{I can understand each word better!}

We can play games in English class. Those words I learned can be used at the board games.

On the other hand, the test anxiety and fears of negative evaluation did not seem to be reduced in the experimental group. This was illustrated in students' feedback:

I am a little nervous. I am going to take the English exam.

\section{I feel lousy if I made a mistake!}

The qualitative evidence highlighted similar findings. The ice-breaking board games did not appear to reduce overall anxieties of the experimental group. However, the communication atmosphere became heated and active, while they remained very worried about the coming English tests or making mistakes when playing games.

\section{Discussions}

Findings from both quantitative and qualitative data indicate results in line with each other: namely, that the ice-breaking board games did not significantly reduce foreign language learning anxiety as a whole. The overall anxiety of the experimental group was not reduced significantly after a 10 -week intervention of ice-breaking board games. However, the anxiety aspect and communication apprehension of the experimental group was slightly appeased, and the test anxiety along with fears of negative apprehension increased in both the descriptive and qualitative analyses.

This might imply that board games are not effective in reducing English learners' overall anxiety. However, both descriptive statistic and qualitative data revealed that ice-breaking board games helped increase the pleasure of learning and created a warm and positive environment for learning English that reduced communication apprehension. Such results indicated that board games might serve better in easing students' communication apprehension. More and better instructional designs integrated with board games can be developed to facilitate learners' spoken English by reducing their communication apprehension.

\section{Conclusion}

Progressive English teachers out of good intentions are looking for innovative methods of teaching to enhance instructional and learning qualities. They would like to integrate new tools or innovative concepts into teaching. However, it is not always the case that new methods are better. The research findings suggest that the ice-breaking board games in English teaching did not effectively reduce students' overall foreign language anxiety. However, the descriptive statistics and qualitative data suggest that the constructs of anxiety of both groups changed in opposite directions, and ice-breaking board games appeared to be more impactful in reducing communication apprehension. This result implies that board games might be especially effective when used in classes of spoken English. More instructional designs should be developed to integrate board games into spoken English classes to reduce learners' communication apprehension. 


\section{References}

Chai, S-C. (2010). English teaching materials and methods. Wunan.

Chang, W. C. (2009). ELT Policies in Taiwan. Crane Publishing.

Chang, Y. C. (2016). The effectiveness of integrating board games into English vocabulary learning [Unpublished master's thesis]. Taipei University of Technology and Science.

Chen, C. Y. (2010). The possibility of applying modern board games on children's learning. New Knowledge of Mandatory Education, 57(4), 40-45.

Cheng, Y. H. (1999). The nature of anxiety in an EFL classroom. English Teaching, 24(4), 1-15.

Cheng, Y. S. (2004). EFL Students' Writing Anxiety:Sources and Implications. English Teaching \& Learning, $29(2), 41-62$.

Chih, P. Y. (2016). An investigation of employing board games to teach $6^{\text {th }}$ graders to enhance their English learning achievements [Unpublished master's thesis]. National Taichung University of Education.

Chou, C. T., Cheng, Y. S., \& Song, C. M. (2009). A study on the relationships of self-efficy, English anxiety, and English learning achievements of the high school students in the Taipei City. Journal of Education \& Pscyhology, 32(2), 82-111.

Duxbury, J. G., \& Tsai, L. L. (2010). The Effects of Cooperative Learning on Foreign Language Anxiety: A Comparative Study of Taiwanese and American Universities. International Journal of Instruction, 3(1), $3-18$.

Education, Parenting and Family. (2015). Parenting board games 100. Education, Parenting and Family Publishing Co.

Gobet, F., Voogt, A. J., \& Retschitzki, J. (2004). Moves in mind: The psychology of board games. Psychology Press. https://doi.org/10.4324/9780203503638

Gregersen, T., \& Horwitz, E. K. (2002). Language learning and perfectionism: Anxious and non-anxious language learners' reactions to their own oral performance. The Modern Language Journal, 86(4), 562-570. https://doi.org/10.1111/1540-4781.00161

Horwitz, E. K., Horwitz, M. B., \& Cope, J. A. (1986). Foreign Language Classroom Anxiety. The Modern Language Journal, 70(2), 125-132. https://doi.org/10.1111/j.1540-4781.1986.tb05256.x

Huang, J. (2012). Overcoming Foreign Language Classroom Anxiety. Nova Science Publishers.

Kottler, E, \& Kottler, J. A. (2001). Children With Limited English: Teaching Strategies for the Regular Classroom. Sage Pubns.

Krashen, S. D. (1982). Principles and practice in second language acquisition. Pergamon Press.

Lee, H. L. J. (2012). SMARTies:Using a board game in the English classroom for edutainment and assessment. Malaysian Journal of ELT Research, 8(1), 1-35.

Liao, H. C. (2007). English Education. Psychological Publishing Co., Ltd.

Lin, Y. Y. (2015). Employing board games to teach students of different learning styles in the elementary lower grades to enhance their learning motivations [Unpublished master's thesis]. National Taipei University of Education.

Liu, C. F., Yeh, T. Y., Tsai, Y. L., Chung, C. C., \& Hsu, H. H.(2015). Integration of educational board game and creative thinking spiral teaching strategies to developing student's imagination and curiosity. Taiwan Educational Review Monthly, 4(9), 101-109.

Lo, Y. W. (2016). The influence of using board goames on six-graders' English vocabulary learning [Unpbulished master's thesis]. University of Taipei.

MacIntyre, P. D., \& Gardner, R. C. (1991). Method and results in the study of anxiety and language learning A review of the literature. Language Learning, 41(1), 85-117. https://doi.org/10.1111/j.1467-1770.1991.tb00677.x

Mostowfi, S., Mamaghani, N. K., \& Khorramar, M. (2016). Designing playful learning by using educational board game for children in the age range of 7-12: a case study: recycling and waste separation education board game. International Journal of Environmental \& Science Education, 11(12), 5454-54. 


\section{Appendix I}

學習回饋單 (A)

五年班號 中文姓名:

英文名字:

親愛的五年級同學:

上完英文課後，有什麼樣的想法呢？ 以下有幾個問題，請踴躍表達你的想法吧！這張回饋單除了你 和研究老師們之外，不會有其他人看見喔! 所以請誠實的發表意見吧!

1. 上英語課會感到緊張焦慮嗎? 為什麼呢?

2. 你覺得邊玩桌遊邊學習英文，帶給你哪些幫助呢? 上課時，會感到緊張焦慮嗎?

3. 給老師的話:

日期： $\mathrm{XX}$ 年（）月（）日 星期（）

\section{Appendix II}

學習回饋單 (B)

五年_班—號 中文姓名:

英文名字:

親愛的五年級同學:

上完英文課後，有什麼樣的想法呢? 以下有幾個問題，請蹈躍表達你的想法吧! 這張回饋單除了你 和研究老師們之外，不會有其他人看見喔! 所以請誠實的發表意見吧!

1. 上英語課會感到緊張焦慮嗎? 為什麼呢?

2. 你覺得學校英語課的學習方式帶給你哪些幫助呢? 上英語課時，會感到緊張焦慮嗎?

3. 給老師的話:

\section{Copyrights}

日期：XX 年（）月（）日 星期（）

Copyright for this article is retained by the author(s), with first publication rights granted to the journal.

This is an open-access article distributed under the terms and conditions of the Creative Commons Attribution license (http://creativecommons.org/licenses/by/4.0/). 